\title{
The Dogs Liver Damage and MicroRNA-122
}

\author{
Aliye SAĞKAN ÖZTÜRK \\ Department of Internal Medicine, Faculty of Veterinary Medicine, University of Hatay Mustafa Kemal, Hatay, TURKEY \\ ORCID: 0000-0003-1037-6733
}

\begin{abstract}
MicroRNAs, a single stranded RNA molecules encoded by the genome, are non-coding RNAs found in all eukaryotic cells and play roles in biological processes such as development, differentiation, apoptosis and growth. MicroRNAs are expressed in many tissues and their uncontrolled increase / decrease in the cell may be related to the damage that occurs in these tissues. MicroRNAs can be specific biomarkers for many diseases due to their high levels of detection in systemic circulation after tissue damage and their extraordinary stability. One of them, miR-122, is a validated biomarker that can be detected in the blood after liver damage in humans. Classical liver function tests (aminotransferases) in dogs, as well as in humans, may be insufficient, especially in revealing chronic liver damage. The reason for this is that aminotransferases are in the reference range, mostly due to the decrease in the number of hepatocytes. Liver biopsy, which is the gold standard in staging liver diseases, is an invasive method and has various complications. For these reasons, the effectiveness of miR-122 in revealing liver damage, especially in advanced and clinical symptoms, has been a research topic in recent years. The aim of this review is to evaluate of miR-122 for some liver diseases and neoplasms in dog.
\end{abstract}

Key words: Dog, Liver Damage, miR-122.

\section{Köpeklerde Karaciğer Hasarı ve MikroRNA-122}

öz

Genom tarafından kodlanan tek iplikli RNA molekülü olan mikroRNA'lar tüm ökaryotik hücrelerde bulunan kodlama yapmayan RNA'lardan olup, gelişim, farklılaşma, apoptoz ve büyüme gibi biyolojik süreçlerde rol oynamaktadır. MikroRNA'lar pek çok dokuda ifade edilmekte ve hücre içerisinde kontrolsüz şekilde artma / azalmaları bu dokularda meydana gelen hasarla ilişkili olabilmektedir. MikroRNA'ların doku hasarından sonra sistemik dolaşımda yüksek seviyelerde tespit edilebilmesi ve olağanüstü kararlılıkları nedeniyle pek çok hastalık için spesifik biyobelirteç olabilir. Bunlardan biri olan miR-122, insanlarda karaciğer hasarından sonra kanda belirlenebilen doğrulanmış bir biyobelirteçtir. İnsanlarda olduğu gibi köpeklerde de klasik karaciğer fonksiyon testleri (aminotransferazlar) özellikle kronik karaciğer hasarını ortaya koymada yetersiz kalabilmektedir. Bunun nedeni çoğunlukla hepatosit sayısındaki azalmaya bağlı olarak aminotransferazların referans aralığı içinde olmasıdır. Karaciğer hastalıklarının evrelenmesinde altın standart olan karaciğer biyopsisi ise invaziv bir yöntem olup çeşitli komplikasyonları vardır. Bu sebeplerden dolayı karaciğer hasarının özellikle ileri ve klinik bulgu göstermeyen dönemde ortaya konulmasında miR-122'nin etkinliği son yıllarda bir araştırma konusu olmuştur. Yapılan bu derlemenin amacı köpeklerde bazı karaciğer hastalıkları ve neoplazilerinde miR-122'nin değerlendirilmesidir.

Anahtar kelimeler: Karaciğer Hasarı, Köpek, miR-122. 


\section{GíRiş}

\section{MikroRNA}

MikroRNA (miRNA) genom tarafından kodlanan, yaklaşık 22 nükleotit uzunluğunda tek iplikli RNA molekülü olarak ifade edilen ve gen ifadesinin düzenlenmesinde rol oynayan non koding RNA'lardandır. Non-coding ifadesi miRNA'ların kodlamayan RNA'lar (ncRNA) olduğunu, yani DNA'dan transkripsiyonu gerçekleştirilip proteine çevrilmeyen genler tarafından kodlandığı anlamını taşımaktadır (Ambros 2004).

MikroRNA yolağı transkripsiyon, nükleer olgunlaşma, çekirdek dışına aktarım ve sitoplazmik kırpılmayı içermektedir. mikroRNA'ları kodlayan bölgeler öncelikle 60-70 baz çiftlik trasnkriptler halinde, saç tokası benzeri öncül pri-miRNA'lar halinde sentezlenir. Ardından bu Pri-miRNA' lar çekirdek içerisinde RNaz III tip enzim olan Drosha-Pasha (insan DGCR8) protein kompleksi tarafından kesilerek pre-miRNA'yı oluştururlar. Pre-miRNA bir nüklear transport reseptörü olan exportin-5 (EXP-5) yardımıyla sitoplazmaya taşınır. Sitoplazma içerisinde pre-miRNA Dicer ve eş protein ile (Drosophila R2D2, insan TRBP) saç tokası yapısını keserek, kısa çift iplikli dubleks miRNA' lara dönüşür ve bu dubleksin bir ipliği olgun miRNA olarak görev yaparken, diğeri nükleazlar tarafından parçalanır (O'Brien ve ark. 2019). Fakat bilinen tüm mikroRNA'lar bu klasik yolak ile (canonical) üretilmemektedir. Klasik olmayan yolak, mRNA'yı kodlayan konakçı genlerin intronlarında bulunan bir tür mikroRNA olan mirtron adı verilen kısa hairpin yapısıdır. Mirtronlar intronların splaysing (ekleme) yolu ile meydana getirilirler ve gen ekspresyonunda işlevleri vardır (Westholm ve Lai 2011).

Tüm ökaryotik hücrelerde bulunan ncRNA'ların bir sınıfı olan miRNA'lar hedef mRNA'ların translasyonel baskılanmasına ve gen sessizleşmesine yol açarak biyolojik süreçte (gelişim, farklılaşma, apoptoz, büyüme ve metabolizma) önemli bir rol oynamakta ve hücre içerisindeki kontrolsüz şekilde azalma/ artışları birçok hastalıkla ilişkilendirilmektedir (Ardekani ve Naeini 2010). miRNA genlerinin yaklaşık \%50'si protein kodlayan genlerin intronlarında veya kodlamayan RNA transkriptleri içinde yer alır. İnsanlarda 2,588 miRNA'nın, insan genlerinin \% 60'ından fazlasını düzenlediği ve hücre büyümesi ve hücre ölümünde hücresel aktivitelerine her yönden katıldığı tahmin edilmektedir (Saini ve ark. 2007). miRNA'ların gen düzenleyici ağların vazgeçilmez bir bileşeni olması nedeniyle, hastalıkların patogenezinde de önemli bir yere sahip olabileceği ve pek çok hastalığın tanı ve tedavisinde büyük rol oynayacağı düşünülmektedir (Ardekani ve Naeini 2010).

MikroRNA'lar doku hasarından sonra sistemik dolaşımda yüksek seviyelerde tespit edilebilmektedir. Bu da miRNA'ların hücresel hasarın ardından salındığını düşündürmektedir. Olağanüstü kararlılıkları, biyolojik sıvılarda tespit kolaylığı ve dokuya özgü ekspresyon modelleri nedeniyle miRNA'lar organ hasarının spesifik biyobelirteçleri olma potansiyeline sahiptir (O'Brien ve ark. 2019). Insanlarda miRNA'lar, hepatit C (miR-122) ve çeşitli kanser türleri dahil olmak üzere pek çok hastalık için birer biyobelirteç olabilirler (Hayes ve Chayama 2016).

Doku mikroRNA'larının doğrudan ölçümü invaziv yöntemlerle elde edilmesi açısından biyobelirteç olarak elverişsizdir. Öte yandan, serum mikroRNA'larının ölçümü çok daha az müdahale gerektirmektedir. Karaciğer gibi bazı organ ve dokulardaki mikroRNA seviyeleri bazı mikroRNA'lar için serum seviyeleri ile ilişkilidir (Shwetha ve ark. 2013). Karaciğerden gelen mikroRNA'lar seruma apoptoz ve nekroz yoluyla pasif olarak veya ekzozomların ve viral partiküllerin salgılanması yoluyla aktif olarak girebilir (Novellino ve ark. 2012).

MikroRNA'lar serum ve dokunun yanı sıra plazma, idrar, tükürük ve beyin omurilik sıvısında da belirlenebilir ve nispeten stabildir (Cortez ve ark. 2011). Serbest RNA, RNazlar tarafından hızla bozulur ve tipik olarak kısa bir yarı ömre sahiptir. Olgun mikroRNA'lar ise çok daha kararlıdır ve normalde protein argonaute-2 (AGO2) veya diğer argonaute proteinleri ile kompleks haldedir. Bu nedenle dondurulmuş numuneler önemli bir bozulma olmadan miRNA analizleri için saklanabilir. Dolaşımdaki mikroRNA'lar, vezikül içermeyen ribonükleoprotein kompleksleri olarak, Hepatit B Virüs yüzey antijeni (HBsAg) partikülleri içinde veya eksozomlar / mikroveziküller içinde yer alabilir veya taşınabilirler. Ancak serum mikroRNA'lar tipik olarak eksozomlarda bulunmaktadır (Arroyo ve ark. 2011, Novellino ve ark. 2012).

Insanlarda olduğu gibi hayvanlarda da miRNA'lar hemen 
hemen hücresel sürecin her aşamasında yer alıp, yine hayvanlarda da gelişim, hücre farklılaşması ve homeostaz için gereklidir (Gebert ve MacRae 2018). miRBase'de (v.21) köpekler için 453, sıçanlar için 765 ve insanlar için ise 2588 açıklamalı olgun miRNA dizisi vardır. Köpek miRNA doku atlası, biyobelirteç keşfi için bir kaynak sağlar. Bununla birlikte, köpek miRNA ekspresyonu veya sekansların açıklamaları hakkında çok az şey bilinmektedir. Son çalışmalar, kemirgen türlerinde ve insanlarda miRNA doku ekspresyonuna odaklanırken, köpekler için önemli bir miRNA veri eksikliği vardır. Oysaki Beagle ırkı köpekler insanlarda ilaç güvenliğinin değerlendirilmesi için önemli bir türdür. Köpekte dokuya özgü yaralanmanın miRNA biyobelirteçlerinin belirlenmesi, insanlarda kullanımı amaçlanan kimyasal bileşiklerin potansiyel olarak olumsuz etkilerinin tahmini ve izlenmesine büyük katkı sağlayacaktır (Koenig ve ark. 2016).

\section{Karaciğer Hasarı ve MikroRNA-122}

Çoğu miRNA, memeli türleri arasında dokuya özgü ekspresyon gösterir. Örneğin farelerde, sıçanlarda, köpeklerde ve insanlarda karaciğer hasarından sonra kanda saptanabilen miR-122 gibi doğrulanmış biyobelirteç örnekleri vardır (Oosthuyzen ve ark. 2018).

Son yıllarda köpeklerde karaciğer hasarının belirlenmesinde mikroRNA'ların kullanımı hepatik mikrozomal fonksiyonun kantitatif değerlendirilmesine olanak sağlamaktadır (Lidbury ve Suchodolski 2016). Karaciğere özgü miR-122'nin, gen ekspresyonunu etkileyerek hepatositlerde hücresel homeostazın sürdürülmesinde, hepatik inflamasyonu, tümör baskılamasını ve lipid metabolizmasını azaltmada önemli işlevleri olduğu bilinmektedir (O'Brien ve ark. 2019). Ek olarak, miR-122 hem plazma hem de karaciğer demir değerlerini düzenler (Castoldi ve ark. 2011) ve karaciğer dışı dokularda neredeyse hiç eksprese edilmez (Landgraf ve ark. 2007). Sağlıklı köpeklere kıyasla fibrotik, inflamatuar ve neoplastik etiyolojilere sahip karaciğer hastalıklarında, alanin transaminaz (ALT) düzeyleri ile kıyaslandığında miR122 konsantrasyonları artmış ve karaciğer hasarı için spesifik biyobelirteç olarak kabul edilmiştir (Oosthuyzen ve ark. 2018).

Karaciğer hasarında köpeklerdeki iki miRNA miR-122 (yüksek doku hassasiyeti) ve ters tamamlayıcı miR-3591'dir. Bunun dışında miR-885'teki yükselmelerde miR-122 gibi karaciğer ile ilişkilendirilmiştir. Hatta ALT ve AST'deki artışlarla bu miRNA artışları korelasyon göstermiş ve bu korelasyon hafif ila orta dereceli hepatoselüler nekrozla doğrulanmıştır. Ancak köpekde bu korelasyon miR-885'te miR-122'den daha yüksek bulunmuş bu iki miRNA'nın köpeklerde karaciğer hasarının potansiyel biyobelirteçleri olarak kullanımını onaylamıştır (Koenig ve ark. 2016).

Alanin transaminaz, aspartat transaminaz (AST), $\gamma$-glutamil transpeptidaz (GGT) ve $\alpha$-fetoprotein gibi serum karaciğer enzim seviyelerindeki değişimler karaciğer fonksiyonu hakkında bilgi sağlar. Ancak bu enzimler böbrek, kas ve kemik gibi bazı dokulardan da salınması nedeniyle sınırlı özgüllüktedir ve daha karmaşık yorumlama gerektirir. Ayrıca bunlar karaciğer hastalıklarında tedavi sırasında kullanılabilmesine rağmen ileri aşamaya kadar tespit edilemeyen hepatosellüler karsinom (HCC) gibi neoplastik hastalıklar için daha erken tespit edilebilen ve hassasiyeti yüksek biyobelirteçlere intiyaç duyulmaktadır (Hayes ve Chayama 2016). Enzimlerin tersine birçok mikroRNA, doku veya organa özgü şekilde ifade edilmesi mikroRNA'ların biyobelirteç olarak daha yüksek özgüllüğe sahip olma olasılığını ortaya koyar. Serumdaki mikroRNA'ların varlığı ve potansiyel biyobelirteç olarak kullanımları ilk olarak Lawrie ve ark. (2008) tarafından diffüz büyük B hücreli lenfomadaki rolleri hakkında yapıımış ve diğer pek çok çalışma bunu takip etmiştir.

Yine karaciğer hasarının klinik biyokimyada en önemli göstergelerinden olan transaminazlar ile miR-122'nin karşılaştırıldığı bir çalışmada, ALT seviyelerinin henüz yükselmediği durumlarda minimal karaciğer hasarı ile miR122 artışları korelasyon göstermiştir. Bu nedenle miR-122'nin standart karaciğer fonksiyon testlerinden daha hassas olabileceği ifade edilmiştir. ALT yükselmesinden önce miR122 seviyelerinde belirlenen artış erken bir biyobelirteç olabileceğini ortaya koymaktadır (Starckx ve ark. 2013).

Köpeklerde yaygın bir karaciğer hastalığı olan kronik hepatit $(\mathrm{CH})$, hepatoselüler apoptoz veya nekroz ile değişken bir inflamatuar hücre infiltrasyonu ve fibrozis ile karakterizedir ve özellikle Labrador Retriever ırkı hastalığa duyarlıdır (Shih 
ve ark. 2007, Poldervaart ve ark. 2009). Alanin aminotransferaz $(A L T)$, genellikle karaciğere en spesifik enzim olarak kabul edilmesine rağmen, yukarıda da ifade edildiği gibi hepatiti tespit etme duyarlıı̆̆ı düşüktür. Ayrıca ilerlemiş fibrozda ALT aktivitesi, hepatosit sayısındaki azalma sonucunda referans aralığı içinde olabilir (Dirksen ve ark. 2017).

Pek çok kronik karaciğer hastalığında karaciğer biyopsisi teşhis için altın standarttır ve nekroinflamatuarın derecesi ve fibrozin evrelenmesini histopatolojik olarak puanlanabilir. Buradaki karaciğer fibroz ifadesi ise hücre dışı matriks (ECM) proteinlerinin artan birikimi olarak tanımlanmaktadır (Favier, 2009). Invaziv ve bazı riskler taşımasına rağmen histopatolojik değerlendirme sadece tanı koymak için değil, aynı zamanda tedavi sırasındaki değişiklikleri izlemek için de gerekli olabilmektedir (Lidbury ve Suchodolski 2016). Bu nedenle, hastalık şiddetini değerlendirmede kullanılmak üzere, minimal invazif olabilecek biyobelirteçlerin arayışı CH'li köpekler için devam etmektedir. Son zamanlarda, dolaşımdaki miR122'nin Labrador Retriever'larda karaciğer hasarı ve hepatik bakır birikimi için miR-122'nin serum düzeylerindeki artışlar ALT'den daha spesifik ve hassas bir biyobelirteç olarak kabul edilmiş ve miR-122'nin hepatopatilerin erken dönem teşhisi ve etkili bir tedaviye de olanak sağlayacaktır (Dirksen ve ark. 2016b). Ek olarak, köpeklerde parankimal, biliyer ve neoplastik hepatobiliyer hastalıkları ayırt etmek için dolaşımdaki mikroRNA'lardan oluşan bir panel kullanılabilir (Dirksen ve ark. 2016a).

Köpeklerde dolaşımdaki spesifik mikro RNA'lar ile fibrozisin ilerlemesi arasındaki ilişki ilk defa Sakai ve ark. (2019) tarafından ortaya konulmuştur ve miR-122 ve miR-29a konsantrasyonlarının köpek CH'nin derece ve evrelenmesinin yanı sıra tedavi ve prognozunun da izlenmesi için yararlı birer belirteç olacağı ifade edilmiştir (Sakai ve ark. 2019). Bir diğer çalışma miR-122 primer hepatitisin akut formu ve kronik aktif hepatitide (CAH) önemli ölçüde eksprese edilirken, miR-21'in sadece CAH'de artış gösterdiğini ortaya koymuş ve bu iki miRNA'yı hastalıkları birbirinden ayırt etmede kullanılabilecek yeni ve invaziv olmayan bir biyobelirteç olarak kabul etmişlerdir (El-Sebaey ve ark. 2020a).

Eman ve ark. (2018), serumda belirlenen hepatosit kaynaklı
miRNA-122'nın köpeklerde hepatosellüler hasarın saptanması için tanısal olarak özellikle aminotransferazların normal serum seviyelere indiği CH'lerde oldukça stabil bir gösterge olduğunu ortaya koymuşlardır. Çalışmanın sonuçlarında serum miRNA-122 düzeyleri, ALT ve AST'de yükselmeye eşlik eden akut hepatitte önemli bir artış göstermenin yanı sıra normal düzeylerde ALT ve AST gözlenen kronik hepatitte de yükselmiştir.

Konjenital portosistemik şantlar (CPSS), köpeklerde hepatobiliyer sistemin en sık görülen vasküler anormalliğidir. CPSS, portal dolaşımdan gelen kanın (toksinler, hepatotrofik maddeler ve besinler ile birlikte) hepatik parankimi baypas etmesi ve doğrudan dolaşım sistemine karışmasına neden olur. Şant damarları cerrahi yolla tedavi edilmektedir. Serum miRNA'ları (cfa-miR-122, cfa-miR-34a, cfa-miR-21 ve cfa-miR-126) farklı CPSS gruplarında potansiyel olarak ifade edilebilirler ve her şant tipinde karaciğerde meydana gelen histopatolojik ve moleküler olayları belirleyebilmek için kullanılabilecek yüksek duyarlılı ve özgüllüğe sahip noninvaziv biyobelirteçler olarak kullanılabilirler (El-Sebaey ve ark. 2020b).

MiR-122 ekspresyonunun köpek birincil tümörlerinde (hepatoselüler karsinom-HCC) ve hücrelerinde azalır ve bu köpeklerde dolaşımdaki miR-122 ekspresyonunun, muhtemelen hasarlı hepatositlerden kan dolaşımına miR-122 salımı sonucunda artmaktadır (Hayes ve Chayama 2016).

MiR - 21, miR - 122, miR - 126, miR - 200c ve miR - 222'den oluşan bir mikroRNA paneli parankimal, biliyer ve neoplastik hepatobiliyer hastalıkları ayırt edebilir. Serum mikroRNA profili, köpeklerde çeşitli hepatobiliyer hastalıkların teşhisine yardımcı olmak için geleneksel teșhis yöntemlerine değerli bir katkı sağlayabilir. Ancak hastalığın ya da tümörün çeşidi bu miRNA'ların değişimlerinde önemli bir etkendir. Örneğin hepatoselüler adenoma'lı (HCA) köpeklerde bunlardan hiç birinde artış gözlenmemesine rağmen, lenfomalı köpeklerde sadece miR-21 ve miR-122 artmıştır. Kontrollere kıyasla lenfoma veya HCC'lu köpeklerde miR - 122'nin yukarı regülasyonu, köpeklerde neoplastik karaciğer hastalığı için potansiyel bir biyobelirteç olarak miR - 122'nin kullanılabileceğini göstermektedir (Dirksen ve ark. 2016a). Bir başka çalışmada 
karaciğer tutulumu olan köpek multisentrik lenfomasında karaciğer hasarını ortaya koymak için miR-122'nin serum düzeylerini güvenilir, daha stabil, invaziv olmayan ve kolayca ölçülebilen tanısal biyobelirteç olarak kabul etmiştir (Ramadan ve ark. 2019). Lai ve ark. (2018) da HCC'da miR-122 aşağı regüle edildiğini ortaya koyarak bazı gen ve miRNA'ların köpek HCC'de anormal şekilde ifade edildiğini söylemişlerdir (Lai ve ark. 2018).

\section{SONUC}

Çalışmaların sonuçları göz önünde bulundurulduğunda köpeklerde karaciğer hastalıklarında klasik karaciğer enzim testlerindeki değişimlerin hastalığın derecesi ve evrelenmesinde yetersizdir. Kesin teşhis yöntemi olan histopatolojik değerlendirmeler ise invaziv olup bazı komplikasyonlara neden olmaktadır.

Özellikle kronik karaciğer hasarının genellikle uzun süreli ve subklinik seyirli olması, ALT'nin erken dönemde karaciğer hasarında artış gösterirken fibrozise kadar ilerleyebilen kronik dönemde normal seviyelerine gerilemesinden dolayı hepatoselüler hasarı gösteren daha güvenilir biyobelirteçlere intiyaç duyulmaktadır.

Güncel keşiflerden biri olan kodlanmayan RNA'lardan olan miRNA'lar karaciğer hastalıklarının teşhisinde son yıllarda noninvaziv bir yöntem olarak güvenle kullanılabilecektir. Ancak akut ve kronik karaciğer hasarında miR-122 seviyelerinde artış meydana gelmesine rağmen HCA gibi bazı karaciğer patolojilerinde artış gözlenmemesi, miR-122'nin yukarı ve aşağı regülasyonları hakkında daha kontrollü çalışmaların yapıIması gerektiğini de ortaya koymaktadır.

\section{ÇIKAR ÇATIŞMASI}

Yazarlar tarafından çıkar çatışması bildirilmemiştir.

\section{FINANSAL DESTEK}

Yazarlar tarafından finansal destek almadıkları bildirilmiştir.

\section{KAYNAKLAR}

Ambros V. (2004). The functions of animal microRNAs. Nature, 431(7006):350-5.

Ardekani AM \& Naeini MM. (2010). The Role of MicroRNAs in Human Diseases. Avicenna journal of medical biotechnology, 2(4):161-179.

Arroyo JD, Chevillet JR, Kroh EM, et al. (2011). Argonaute2 complexes carry a population of circulating microRNAs independent of vesicles in human plasma. Proc. Natl. Acad. Sci. USA, 108:5003-5008.

Castoldi M, Vujic Spasic M, Altamura S, et al. (2011). The liver-specific microRNA miR-122 controls systemic iron homeostasis in mice. The Journal of Clinical Investigation, 121:1386-1396.

Cortez MA, Bueso-Ramos C, Ferdin J, et al. (2011). MicroRNAs in body fluids-The mix of hormones and biomarkers. Nat. Rev. Clin. Oncol, 8:467-477.

Dirksen K, Burgener IA, Rothuizen J, et al. (2017). Sensitivity and specificity of plasma ALT, ALP, and bile acids for hepatitis in Labrador Retrievers. J Vet Intern Med, 31:10171027.

Dirksen K, Verzijl T, Grinwis GC, et al. (2016A). Use of serum microRNAs as biomarker for hepatobiliary diseases in dogs. J Vet Intern Med, 30:1816-1823.

Dirksen K, Verzijl T, van den Ingh TS, et al. (2016B). Hepatocytederived microRNAs as sensitive serum biomarkers of hepatocellular injury in Labrador retrievers. Vet J, 211:7581.

El-Sebaey AM, Abramov PN, Borunova SM, (2020A)Cfa-miRNAs 122 and -21 as modern biomarkers of primary hepatitis in dogs. RUDN Journal of Agronomy and Animal Industries, 15(3):294-307.

El-Sebaey AM, Abramov PN, Abdelhamid FM, (2020B). Clinical Characteristics, Serum Biochemical Changes, and Expression Profile of Serum Cfa-miRNAs in Dogs Confirmed to Have Congenital Portosystemic Shunts Accompanied by Liver Pathologies. Vet Sci, 25:7(2):35.

Eman SR, Kubesy AA, Baraka TA, et al. (2018). Evaluation of hepatocyte-derived microRNA-122 for diagnosis of acute and chronic hepatitis of dogs. Vet World, 11(5):667-673.

Favier RP. (2009). Idiopathic hepatitis and cirrhosis in dogs. Veterinary Clinics of North America: Small Animal Practice, 39:481-488.

Gebert LFR, MacRae IJ. (2019). Regulation of microRNA function in animals. Nat Rev Mol Cell Biol, 20(1):21-37.

Hayes CN, Chayama K, (2016). MicroRNAs as biomarkers for liver disease and hepatocellular carcinoma. Int J Mol Sci, 17:280.

Koenig EM, Fisher C, Bernard H, et al. (2016). The beagle dog MicroRNA tissue atlas: identifying translatable biomarkers of organ toxicity. BMC Genomics, 17:649.

Lai YC, Ushio N, Rahman MM, et al. (2018). Aberrant expression of microRNAs and the miR-1/MET pathway in canine 
hepatocellular carcinoma. Vet Comp Oncol, 16(2):288-296.

Landgraf $\mathrm{P}$, R usu M, Sheridan R, et al. (2007). A mammalian microRNA expression atlas based on small RNA library sequencing. Cell, 129:1401-1414.

Lawrie CH, Gal S, Dunlop HM, et al. (2008). Detection of elevated levels of tumour-associated microRNAs in serum of patients with diffuse large B-cell lymphoma. Br. J. Haematol, 141:672-675.

Lidbury JA, Suchodolski JS, (2016). New advances in the diagnosis of canine and feline liver and pancreatic disease. Vet J, 215:87-95.

Novellino L, Rossi RL, Bonino F, et al. (2012). Circulating hepatitis b surface antigen particles carry hepatocellular microRNAs. PLoS ONE, 7:e31952.

O'Brien A, Zhou T, Tan C, et al. (2019). Role of Non-Coding RNAs in the Progression of Liver Cancer: Evidence from Experimental Models. Cancers, 11(11): 1652.

Oosthuyzen W, Ten Berg PWL, Francis B, et al. (2018). Sensitivity and specificity of microRNA-122 for liver disease in dogs. J Vet Intern Med, 32(5):1637-1644.

Poldervaart JH, Favier RP, Penning LC, et al. (2009). Primary hepatitis in dogs: a retrospective review (2002-2006). J Vet Intern Med, 23:72-80.

Ramadan ES, Kubesy AA, Baraka TA, et al. (2019). Expression of blood hepatocyte-derived microRNA-122 in canine multicentric lymphoma with hepatic involvement. Vet Res Commun, 43(4):231-238.

Saini HK, Griffiths-Jones S, Enright AJ. (2007). Genomic analysis of human microRNA transcripts. Proc Natl Acad Sci U S A, 6;104(45):17719-24.

Sakai M, Spee B, Grinwis GCM, et al. (2019). Association of circulating microRNA-122 and microRNA-29a with stage of fibrosis and progression of chronic hepatitis in Labrador Retrievers. J Vet Intern Med, 33(1):151-157.

Shih JL, Keating JH, Freeman LM, et al. (2007). Chronic hepatitis in Labrador Retrievers: clinical presentation and prognostic factors. J Vet Intern Med, 21:33-39.

Shwetha S, Gouthamchandra K, Chandra M, et al. (2013). Circulating miRNA profile in HCV infected serum: Novel insight into pathogenesis. Sci. Rep, 3:1555.

Starckx S, Batheja A, Verheyen GR, et al. (2013). Evaluation of miR-122 and other biomarkers in distinct acute liver injury in rats. Toxicol Pathol, 41(5):795-804.

Westholm J0, Lai EC. (2011). Mirtrons: microRNA biogenesis via splicing. Biochimie, 93(11):1897-904. 